\title{
HUBUNGAN MOTIVASI DENGAN PRAKTIK PERAWAT DALAM PENCEGAHAN RESIKO JATUH PADA ANAK DI RUMAH SAKIT KABUPATEN KENDAL
}

\author{
Sulastri ${ }^{1}$, Budi Wahyudi ${ }^{2}$ \\ ${ }^{1}$ STIKES Muhammadiyah Kendal \\ ${ }^{2}$ RSUD Kendal \\ Email : $\underline{\text { sulastri.jihan@yahoo.co.id }}$
}

\begin{abstract}
ABSTRAK
Resiko jatuh rentan terjadi pada pasien sehingga motivasi perawat perlu dalam pencegahan resiko jatuh pada anak.Perawat dituntut untuk mencegah terjadinya jatuh pada pasien dalam perawatan. Penelitian ini bertujua nuntuk mengetahui hubungan motivasi dan praktik perawat dan hubungan antara motivasi dan praktik perawat dalam pencegahan resiko jatuh pada anak. Penelitian ini menggunakan desain penelitian korelasi dengan rancangan penelitian cross sectional. Teknik pengambilan sampel menggunakan total sampling dengan jumlah sampel sebanyak 108 responden. Alat pengumpulan data menggunakan kuesioner motivasi dan praktik perawat. Analisa data menggunakan uji Sperman Rank. Pengolahan data dilakukan secara univariat dan bivariat. Hasil penelitian menunjukkan motivasi baik dengan praktik perawat baik sebanyak 47 (43,5\%), motivasi cukup dengan praktik perawat baik sebanyak 14 (13\%), motivasi baik dengan praktik perawat sedang $22(20,4 \%)$, motivasi cukup dengan praktik perawat sedang sebanyak 25 $(23,1 \%)$. Ada hubungan motivasi dengan praktik perawat dalam pencegahan resiko jatuh pada anak. Di Ruang Rawat Inapp value 0,01. $(<0,05)$. Saran untuk meningkatkan motivasi perawat dalam pencegahan resiko jatuh pada anak sehingga resiko jatuh pada anak tidak akan terjadi
\end{abstract}

Kata kunci: Motivasi ,Praktik Perawat, Pencegahan Resiko Jatuh 


\title{
MOTIVATION RELATIONSHIP WITH NURSE PRACTICES IN PREVENTING THE RISK OF FALL IN CHILDREN AT KENDAL DISTRICT HOSPITAL
}

\begin{abstract}
The risk of falling is susceptible to the patient so that nurse motivation is necessary in preventing the risk of falling child. Nurses are required to prevent falls in patients in care. This study aims to determine the relationship of motivation and practice of nurses and the relationship between motivation and practice of nurses in preventing the risk of falling on the child. This research uses correlation research design with cross sectional design. The sampling technique used total sampling with total sample as much as 108 respondents. The data collection tool uses motivational questionnaire and nursing practice. Data analysis using Sperman Rank test. Data processing is done univariat and bivariat. The results showed good motivation with good nurse practice as much as 47 (43,5\%), enough motivation with good nurse practice as much 14 (13\%), good motivation with practice nurse is $22(20,4 \%)$, enough motivation with practice nurse while as many as 25 (23.1\%). There is a motivational relationship with the practice of nurses in preventing the risk of falling In the Inpatient Room p value 0.01. (<0.05). Suggestions to improve nurse motivation in preventing risk of falling in children so that the risk of falling in children will not happen.
\end{abstract}

Keywords: Motivation ,PracticeNurse , PreventionRisksFall down

\section{PENDAHULUAN}

Rumah sakit merupakan tempat pelayanan kesehatan yang melayani rawat inap maupun rawat jalan. Menurut Sunjoto pelayanan kepada pasien di rumah sakit sudah selayaknya merupakan pelayanan yang holistic, pelayanan yang paripurna. Mulai pasien datang melakukan pendaftaran, pemeriksaan, hingga pasien pulang. Akan tetapi beberapa kejadian di rumah sakit kadang tidak diperhatikan, yaitu pasien jatuh pada saat mendapatkan pelayanan di rumah sakit.(Oktaviani, 2015).
Program patient safety di rumah sakit itu sendiri sudah diatur didalam Pasal 8 PERMENKES (Peraturan Menteri Kesehatan) Nomor 1691 Tahun 2011 tentang Keselamatan Pasien yang menyatakan bahwa sasaran keselamatan pasien dirumah sakit meliputi : 1) identifikasi dan pengelolaan hal yang berhubungan dengan pasien, 2) meningkatkan komunikasi yang efektif saat operan pasien, 3) pengendalian cairan elektrolit pekat dan akurasi ketepatan pemberian obat, 4) perawat memastikan tepat lokasi, tepat prosedur, tepat pasien saat akan dilakukan operasi, 5) 
meminimalkan timbulnya resiko infeksi, 6) dan mencegah terjadinya cedera yang disebabkan oleh kesalahan akibat melaksanakan suatu tindakan atau tidak mengambil tindakan yang seharusnya diambil.

World Health Organization (WHO) pada tahun 2009 mengumpulkan angka - angka penelitian rumah sakit di berbagai Negara : Amerika, Inggris, Denmark, dan Australia, ditemukan KTD (Kejadian Tidak Diharapkan) dengan rentang $3.2-16,6 \%$. Data - data tersebut menjadikan pemicu berbagai negara segera melakukan penelitian dan mengembangkan system keselamatan pasien (Bawel, S. C, Sinolungan, J. S. V dan Hamel, R.S. 2013). Survei yang dilakukan oleh Morse pada tahun 2008 tentang kejadian pasien jatuh di Amerika Serikat menunjukan 2,3-7/1000 pasien jatuh dari tempat tidur setiap hari. Survey tersebut menunjukan bahwa 29$48 \%$ pasien mengalami luka ringan dan $7,5 \%$ dengan luka-luka serius. (Prabowo, 2014).

Praktik perawat merupakan suatu rangkaian kegiatan untuk mengurangi atau menghindari terjadinya kejadian jatuh terhadap pasien anak yang dapat mengakibatkan pasien tersebut cidera atau nyaris cidera.

Barbara J. Watson mengatakan dalam penelitiannya jika alat skrining resiko jatuh lebih disukai sebagai bagian dari program pencegahan kejatuhan rumah sakit, analisis validitas prediktif harus dilakukan sebelum diadopsi secara penuh. Skor cut-off yang masuk akal perlu diidentifikasi sesuai dengan setting dengan keseimbangan yang telah ditentukan antara sensitivitas dan spesifisitas. Ini akan memberikan skor resiko jatuh yang lebih akurat dan mengurangi beban perawat yang tidak perlu dihadapi setiap hari. Jika merenungkan program pencegahan jatuh tanpa menggunakan alat skrining, rencana perawatan individual perlu dilakukan dengan panduan tindak lanjut dan intervensi yang jelas. Staf interdisipliner akan mewajibkan pendidikan pada semua aspek pasien terjatuh. Meski ada keterbatasan, ada keuntungan dalam ukuran sampel besar yang digunakandalam penelitian ini juga memberikan rekomendasi praktis yang bertujuan mengurangi resiko jatuh pasien (Prabowo \& Khoiriyati, 2014).

Kongres XII PERSI (Perhimpunan Rumah Sakit Indonesia) di Jakarta pada tanggal 8 November 2012 melaporkan bahwa kejadian pasien jatuh di Indonesia pada bulan Januari-September 2012 sebesar 14\%. Hal ini membuat presentasi pasien jatuh termasuk ke dalam lima besar insiden medis selain medicine error. Data di Indonesia tentang pasien jatuh berdasarkan provinsi pada tahun 2010 di temukan Jawa Barat 33,33\%, Banten dan Jawa Tengah 20\%, DKI 16,67\% dan JawaTimur 3,33\% (Prabowo \& Khoiriyati,2014).

Data yang terkait dengan keselamatan pasien menurut Meliana (2014) di Rumah Sakit Stella Maris dari laporan pencatatan patientsafety tahun 2013. Setidaknya ada tiga belas jenis insiden keselamatan pasien diantaranya : salah pemberian obat dari bagian farmasi (16\%), salah pemberian obat di rawat inap (6\%), salah diagnose 
(6\%), salah distribusi obat dari farmasi (13\%), nyaris salah aplosing obat (3\%), salah interpretasi (3\%), salah mengetik hasil lab/RO (6\%), salah menyediakan obat (3\%), pasien jatuh (9\%), kejadian potensial cidera (9\%), kejadian sentinel (3\%), salah mengambil obat (3\%) dan KTD lain (14\%). Pada triwulan 1 Januari-April 2011, laporan insiden keselamatan pasien dari KKP-RS (Komite Keselamatan Pasien Rumah Sakit) didapatkan 34 laporan insiden, dan sebanyak $19,58 \%$ tim keperawatan memiliki andil dalam keselamatan pasien hal ini karenakan perawat memiliki waktu yang lebih lama dalam memberikan asuhan keperawatan pada pasien.

Usia 5 sampai 14 tahun merupakan periode pertumbuhan dan perkembangan yang beresiko tinggi mengalami cedera karena anak sedang mengembangkan motorik kasar serta memiliki rasa keingintahuan yang tinggi. Cedera pada anak menjadi masalahkesehatan umum yang kejadianya makin meningkat dan membutuhkan perhatian khusus. WHO (2014) menyebutkan bahwa sekitar 230.000 kematian terjadi pada anak usia 5-14 tahun. Setiap tahun, puluhan juta anak membutuhkan perawatan karena cedera, banyak diantaranya mengalami cacat seumur hidup.

Lubis (2016) menyatakan bahwa tingkat resiko cedera lebih tinggi pada anak lakilaki sebanyak 53,8\% dibandingkan dengan anak perempuan. Anak sekolah yang pernah mengalami cedera sebanyak $94,5 \%$. Kasus cedera tertinggi yang pernah dialami adalah jatuh sebanyak 75,6\%. Resiko cedera pada anak usia sekolah dengan tingkat resiko sedang sebanyak $60,4 \%$, rendah $36,3 \%$ dan tinggi 3,3\%.

Penelitian yang dilakukan oleh Winingsih (2019) tentang tingkat pengetahuan pencegahan cedera pada siswa kelas V SD di Kota Bandung didapatkan hasil tingkat pengetahuan pencegahan cedera pada siswa dengan pengetahuan baik sebanyak 12 responden $(16,4 \%)$, pengetahuan cukup 31 responden $(42,5)$ dan pengetahuan kurang 30 responden $(41,1 \%)$.

Menurut penelitian yang dilakukan oleh Sugeng Budiono tentang Pelaksanaan Program Manajemen Pasien dengan Resiko Jatuh di Rumah Sakit. Hasil identifikasi proses akar masalah manajemen resiko pasien jatuh belum optimal terletak pada tingkat perencanaan, sehingga dalam menetapkan akar masalah dilakukan dengan analisis tulang ikan (fishbone) atau diagram Ishikawa. Hasil analisis menunjukkan bahwa sistem manajemen belum berjalan karena belum ditunjang dengan implementasi pada semua komponen yaitu pelaksana, standar operasional yang belum ditetapkan serta sarana yang tidak adekuat (Budiono, 2014).

Berdasarkan hasil penelitian tentang hubungan pengetahuan dan sikap perawat dengan pelaksanaan keselamatan pasien (patient safety) di ruang rawat inap RSUD Liun Kendage Tahuna di Sulawesi Utara dapat disimpulkan sebagai berikut: Ada hubungan pengetahuan perawat dengan pelaksanaan keselamatan pasien (patient safety) di Ruang Rawat Inap RSUD Liun Kendage Tahuna, dimana $95 \%$ perawat 
pelaksana mempunyai pengetahuan baik tentang pelaksanaan keselamatan pasien, dan ada hubungan sikap perawat dengan pelaksanaan keselamatan pasien (patient safety) di Ruang Rawat Inap RSUD Liun Kendage Tahuna, dimana $95 \%$ perawat pelaksana mempunyai sikap yang baik dalam melaksanakan keselamatan pasien. (Bawelle, 2013).

Resiko jatuh pasien di rumah sakit dipengaruhi oleh beberapa faktor antara lain motivai kerja dan komitmen kerja. Menurut Winardi motivasi kerja adalah proses yang bersifat internal atau eksternal bagi setiap pegawai yang menyebabkan timbulnya sikap antusias dan persistensi dalam melaksanakan tugas. Penelitian Sanusi dan Hasnita (2005) di RS Dr. Achmad Bukit Tinggi menunjukkan bahwa motivasi kerja berhubungan dengan karakteristik dan iklim organisasi dan terjadi peningkatan sebesar $15,1 \%$ (Krisnawati, 2016).

Fenomena motivasi kerja perawat masih rendah, dimana perawat belum mampu memberikan pelayanan kesehatan yang terbaik, ini terlihat masih banyaknya keluhan ketidakpuasan pasien dan keluarga atas sikap dan perilaku kerja pegawai, terutama tenaga keperawatan diruang rawat inap (Makta, 2009). Menurut Herzberg dalam Ilyas, yang dimaksud dengan faktor motivasi adalah hal-hal yang mendorong berprestasi yang sifatnya intrinsik, yang berarti bersumber dari dalam diri seseorang, sedangkan yang dimaksud dengan faktor higiene atau pemeliharaan adalah faktor-faktor yang sifatnya ekstrinsik yang berarti bersumber dari luar diri seseorang, misalnya dari organisasi, tetapi turut menentukan perilaku seseorang dalam kehidupannya dalam melaksanakan pekerjaan (Makta, 2013).

Hasil survei dan wawancara dengan beberapa perawat di kabupaten Kendal pada bulan Januari 2020, ada 15 orang tua yang mengatakan tidak tahu dengan mendampingi tidur anaknya dengan posisi yang tidak aman dan akan menimbulkan jatuh dan ada 3 pasien anak yang sudah jatuh. Apabila hal tersebut dibiarkan dan tidak mendapatkan penanganan, maka akan menimbulkan dampak yang tidak baik terhadap pelayanan keperawatan. Dengan fenomena tersebut mendasari penulis untuk melakukan penelitian.

\section{METODE PENELITIAN}

Jenis penelitian menggunakan penelitian kuantitatif dengan desain deskriptif korelasi. Dengan pendekatan cross sectional, sampel dalam penelitian ini sebanyak 108 perawat yang ada di ruang anak rumah sakit se Kabupaten Kendal.Teknik pengambilan sampel dengan cara total sampling. Penelitian ini dilakukan di RSUD Dr. H. Soewondo Kendal, RSI Kendal dan RS Baitul Hikmah Kendal. Instrumen dalam penelitian ini menggunakan kuesioner tentang variabel motivasi yang terdiri dari 13 pertanyaan dan variabel praktik perawat sebanyak 18 pertanyaan. Teknik analisa data yang digunakan dalam penelitian ini menggunakan uji statistik rank spearman 


\section{HASIL PENELITIAN}

\begin{tabular}{lllcccc}
\hline & \multicolumn{7}{c}{5} \\
\hline Total & 47 & 43,5 & 61 & 56, & 108 & 100 \\
& & & 5 & & \\
\hline
\end{tabular}

Tabel 1: Motivasi Perawat Dalam Pencegahan Resiko Jatuh pada anak

Berdasarkan tabel 3 diatas didapatkan

\begin{tabular}{clcc}
\hline No & Motivasi & Jumlah & $\%$ \\
\hline 1. & Baik & 69 & 63,9 \\
\hline 2. & Cukup & 39 & 36,1 \\
\hline 3. & Kurang & 0 & 0 \\
\hline Jumlah & 108 & 100 \\
\hline
\end{tabular}
bahwa dari 39 orang $(36,1 \%)$ yang cukup mendapat motivasi terdapat 25 orang $(23,1 \%)$ dengan praktik perawat dalam pencegahan resiko jatuh sedang dan 14 orang (13\%) tergolong baik. Sedangkan 69

Berdasarkan pada tabel 1 diatas, diperoleh data responden cukup mendapatkan motivasi sebanyak 39 orang $(36,1 \%)$. Sedangkan responden yang mendapat motivasi dengan kategori baik sebanyak 69 orang $(63,9 \%)$

Tabel 2 : Praktik Perawat Dalam Pencegahan Resiko Jatuh pada anak

\begin{tabular}{clcc}
\hline No & Praktik Perawat & Jumlah & $\%$ \\
\hline 1. & Baik & 54 & 50,0 \\
\hline 2. & Sedang & 54 & 50,0 \\
\hline 3. & Buruk & 0 & 0 \\
\hline Jumlah & & 108 & 100
\end{tabular}

Berdasarkan tabel 2 diatas, diperoleh data sebagian besar responden terkategori kurang sepenuhnya sebanyak 54 orang $(50,0 \%)$. Sedangkan responden yang terkategori baik sebanyak 54 orang $(50,0 \%)$

Tabel 3 : Hubungan Motivasi dengan Praktik Perawat Dalam Pencegahan Resiko Jatuh pada anak

\begin{tabular}{cccccccc}
\hline \multirow{2}{*}{$\begin{array}{c}\text { Motiv } \\
\text { asi }\end{array}$} & Sedang & \multicolumn{3}{c}{ Baik } & \multicolumn{2}{c}{ Total } & $\begin{array}{c}p \\
\text { value }\end{array}$ \\
\cline { 2 - 7 } & $\mathrm{N}$ & $\%$ & $\mathrm{~N}$ & $\%$ & $\mathrm{~N}$ & $\%$ & \\
\hline Cukup & 25 & 23,1 & 14 & 13 & 39 & 36,1 & 0,012 \\
\hline Baik & 22 & 20,4 & 47 & 43, & 69 & 63,9 & \\
\hline
\end{tabular}
orang $(63,9 \%)$ yang tergolong motivasi baik terdapat 22 orang $(20,4 \%)$ dengan praktik perawat dalam pencegahan resiko jatuh sedang dan 47 orang $(43,5 \%)$ tergolong dalam kategori baik.

Ada hubungan antara motivasi dengan praktik perawat dalam pencegahan resiko jatuh pada anak dengan nilai $\mathrm{p}$ value $=$ $0,012<0,05$. Nilai spearman rank correlation sebesar 0,312 menunjukkan bahwa pengaruh motivasi terhadap praktik perawat dalam pencegahan resiko jatuh pada anak sebesar $31,2 \%$ sedangkan $68,8 \%$ dipengaruhi oleh faktor lain yang tidak dibahas dalam penelitian ini.

\section{PEMBAHASAN}

Dari analisis univariat diketahui bahwasannya sebagian besar perawat yang menjadi responden dalam penelitian ini tergolong motivasi cukup yakni ada 39 orang $(36,1 \%)$. Sedangkan yang terkategori mendapat motivasi dengan kategori baik sebanyak 69 orang $(63,9 \%)$ responden.

Motivasi menurut Azwar (2019) merupakan suatu penggerak perilaku seseorang secara optimal, hal ini disebabkan karena adanya motivasi berupa 
perubahan kondisi internal, kejiwaan dan mental manusia seperti keinginan, harapan, kebutuhan, dorongan dan kesukaan yang mendorong individu untuk berperilaku kerja guna mencapai tujuan yang diinginkannya, Agar seseorang dapat melakukan sesuatu yang diharapkan, maka harus ada perangsang yang dapat menggerakkan seseorang tersebut untuk bertindak. Perangsang dibedakan atas dua macam yaitu: perangsang positif dan perangsang negative.

Perangsang Positif adalah suatu penghargaan yang diberikan kepada pegawai yang dianggap berprestasi dan layak dipromosikan. Pemberian dapat diberikan berupa hadiah bangkan memberikan kenaikan jabatan yang layak untuk di emban dan dilaksanakan oleh pegawai. Sedangkan perangsang negative merupakan suatu tindakan yang tidak menyenangkan berupa hukuman bagi pegawai yang berbuat kesalahan atau tidak disiplin dalam melaksanakan tugas. Hukuman ini dapat berupa denda atau sanki yang setidaknya dapat membuat pegawai jera dan tidak melakukan kesalahan lagi.

Hal ini sesuai dengan apa yang peneliti dapatkan di lapangan. Bahwasannya motivasi perawat dalam pencegahan resiko jatuh pada anak cukup dapat diartikan dengan perlunya motivasi terhadap pencegahan resiko jatuh, perawat dalam melakukan pencegahan perlu diperhatikan bagaimana kondisi pasien saat dirawat apakah memerlukan penanganan lebih lanjut dan pengawasan yang tinggi. Motivasi perawat cukup dikarenakan sebab sebab yang membuat mereka akan berkunjung kepada pasien tanpa ada kesadaran tersendiri bahwa kita perlu melihat kondisi pasien sesering mungkin. Mereka hanya datang ke pasien jika pasien butuh bantuan. Pasien dibiarkan di kamar. perawat hanya datang pada saat tertentu saja seperti waktu makan atau minum obat. Kebersihan pasien juga kurang di jaga. Pasien jarang diurus. Pasien hanya akan dibantu jika pasien memerlukan bantuan kepada perawat sehingga tugas perawat akan banyak dilakukan oleh anggota keluarga dengan pengetahuan minim tentang kesehatan bagi pasien dengan resiko jatuh.

Padahal dalam diri seseorang terdapat motivasi untuk melakukan hal - hal yang membangun dan memberikan tujuan yang positif yang nantinya dapat mempermudah jalan yang akan ditempuh dari tujuan awal yang direncanakan sesuai dengan Hadist riwayat At Tirmidzi “ Tidak ada manusia yang diciptakan gagal, yang ada hanyalah mereka yang gagal memahami potensi diri dan gagal merencanakan kesuksesannya, tiada yang lebih berat timbangan Allah pada hari akhir nanti, selain Taqwa dan akhlak mulia seperti wajah dipenuhi senyum untuk kebaikan dan tidak menyakiti sesama".

Secara psikologis motivasi perawat untuk melakukan pencegahan dalam menangani resiko jatuh pada anak dapat di aplikasikan dengan tindakan sehari - hari seperti tindakan keperawata dan membantu kebutuhan pasien. Pada umunya pasien akan lebih senang jika mendapatkan pelayanan yang baik oleh perawat sesuai dengan teori Abraham Maslow bahwa 
Motivasi manusia timbul karena adanya kebutuhan- kebutuhan yang diperlukan oleh pasien seperti kebutuhan fisiologis, rasa aman nyaman, kebutuhan social, penghargaan dan aktualisasi diri.

Gambaran Praktik Perawat Dalam Pencegahan Resiko Jatuh Pada Anak.

Dari analisis univariat diketahui bahwasannya sebagian besar perawat dalam pencegahan resiko jatuh pada anak yang menjadi responden dalam penelitian ini tergolong sedang sepenuhnya yakni ada 54 orang $(50 \%)$. Sedangkan responden yang terkategori baik sebanyak 54 orang $(50 \%)$.

Perawat adalah suatu tanggung jawab dalam menjalankan perannya sebagai seorang perawat atau pemberi asuhan kesehatan yang memberikan perawatan sesuai dengan tahapan proses keperawatan dengan tahap - tahap penyembuhan yang seusai dengan lebih menekankan terhadap kepuasan pelayanan terhadap pasien supaya terjalin ikatan yang baik antara perawat dan pasien. Praktik perawat dalam menanggapi suatu respon seseorang terhadap stimulus yang berkaitan dengan sakit dan penyakit sebagaimana praktik dalam pencegahan penyakit merupakan pencegahan penyakit dalam mencegah terjadinya kecelakaan atau sakit yang tidak diinginkan ( Wawan, Dewi, 2011)

Praktik merupakan seluruh kegiatan atau aktivitas manusia, baik yang diamati secara langsung, maupun yang tidak diamati dari pihak luar. Setiap individu memiliki perilakunya sendiri yang berbeda dengan individu lain. Namun, secara minimal jika didasari oleh pengetahuan yang cukup, perilaku positif akan terbentuk relatif lama. Dalam memberikan asuhan keperawatan juga terdapat tugas mulia yang beriringan dalam menjalankan tugas dan tanggung jawab seorang perawat sesuai dengan surat Qs Yunus ayat 57 “ Hai manusia, sesungguhnya telah datang kepadamu pelajaran dari Tuhanmu dan peyembuh - penyembuh bagi penyakit penyakit (yang berada) dalam dada dan petunjuk dan rahmat bagi orang - orang yang beriman". Surat ini menunjukan bahwa Allah SWT telah memberikan petunjuk untuk menjaga kaumnya supaya tidak jatuh pada penyakit yang berbahaya serta menjaga supaya selalu menjaga kesehatan supaya terhindar dari penyakit yang berbahaya bagi dirinya. Untuk itu praktik perawat dibutuhkan untuk menjaga pasien yang dalam kondisi terminal atau dengan kemandirian yang kurang supaya tidak terjadi kecelakaan atau menambah penyakit yang parah dan menyusahkan diri pasien.

Dari berbagai kuensioner yang ditanyakan kepada perawat tentang praktik perawat dalam pencegahan resiko jatuh pada anak, terdapat 3 kategori dalam praktik perawat dalam pencegahan resiko jatuh yakni baik, sedang dan buruk dalam pencegahan pada anak dengan resiko jatuh. Dalam kuensioner tersebut di dapatkan beberapa kategori yang dominan dalam penelitian ini yaitu masuk dalam kategori baik dan sedang. Praktik keperawatan tanpa adanya komunikasi akan terasa tidak begitu masuk dalam pelayanan kepada pasien yang nantinya akan menjadi penilaian 
tersendiri oleh pasien. praktik yang baik juga memerlukan kualitas yang baik juga dalam mememberikan pelayanan dan ilmu yang mumpuni sehingga pasien tidak ragu dan yakin terhadap perawat.

Hubungan Motivasi dengan Praktik Perawat Dalam Pencegahan Resiko Jatuh pada anak

Berdasarkan hasil penelitian menunjukkan bahwa ada hubungan antara motivasi dengan praktik perawat dalam pencegahan resiko jatuh pada anak. Hasil ini didasarkan pada hasil $\mathrm{p}$ value $=0,01$ $(0,01<0,05)$ sehingga Ho ditolak, berarti ada hubungan yang signifikan antara variabel motivasi dengan praktik perawat dalam pencegahan resiko jatuh pada anak.

Nilai spearman rank correlation sebesar 0,01 menunjukkan bahwa ada hubungan motivasi terhadap praktik perawat dalam pencegahan resiko jatuh pada anak. Diketahui dari 39 orang $(36,1 \%)$ yang cukup mendapat motivasi perawat terdapat 25 orang $(23,1 \%)$ dengan kategori praktik perawat dalam pencegahan resiko jatuh yaitu sedang dan 14 orang (13\%) dengan kategori baik.

Dalam penelitian ini dari 69 orang $(63,9 \%)$ yang mendapat motivasi perawat tergolong baik terdapat 22 orang $(20,4 \%)$ dengan kategori praktik perawat dalam pencegahan resiko jatuh yaitu sedangdan 47 orang $(43,5 \%)$ dengan kategori baik. Hal ini sejalan dengan penelitian yang dilakukan Komang Menik Sri K pada tahun 2016 dengan judul "Hubungan Motivasi dan Komitmen Kerja Perawat dengan Penerapan Keselamatan pasien di Ruang
Intensif RSUP Sanglah Denpasar”. Yang menyatakan bahwa ada hubunganantara motivasi dengan Penerapan Keselamatan pasien.

Dalam memberikan pelayanan yang bermutu dan memuaskan pasien, perawat harus mempunyai motivasi yang menyertai tindakan dan kegiatan yang nantinya akan memberikan asuhan keperawatan sesuai dengan surat Al Zalzalah ayat 7-8 “ Barang siapa mengerjakan kebaikan walaupun sebesar zarrah, niscaya ia akan melihat (balasannya di hari kiamat), dan barang siapa mengerjakan kejahatan walaupun sebesar zarrah, niscaya ia akan melihat (balasannya ) pula.

Motivasi menurut Sadili (2010) merupakan konsep yang dipakai untuk menguraikan keadaan ekstrinsik yang ditampilkan dalam perilaku yng terdiri dari respons instrinsik danekstrinsik. Respon instrinsik disebut juga sebagai motif (pendorong) yang mengarahkan perilaku ke rumusan kebutuhan atau pencapaian tujuan sedangkan stimulus ekstrinsik dapat berupa hadiah atau insentif, mendorong individu melakukan atau mencapai sesuatu. Jadi motivasi adalah interaksi instrinsik dan ekstrinsik yang dapat dilihat dengan adanya perilaku atau penampilan. Motivasi dapat menimbulkan suatu rangsangan, dorongan kepada masyarakat atau kelompok untuk mau berbuat dan bekerja sama secara optimal melaksanakan sesuatu yang telah direncanakan. Secara sederhana motivasi dapat dilakukan oleh individu itu sendiri tanpa adanya impuls dari luar, secara dini dapat membuat individu dapat bergerak atau melakukan aktivitas yang nantinya 
dapat mempengaruhi kegiatan individu sendiri. Motivasi perawat dalam melakukan pencegahan resiko jatuh pada pasien dengan resiko jatuh merupakan suatu rencana yang nantinya dapat memberikan tindakan lebih lanjut kepada pasien supaya nantinya terjaga agar tidak terjadi jatuh dan menjadikan kecacatan yang fatal kepada pasien dengan kondisi terminal.

Praktik perawat dalam pencegahan resiko jatuh merupakan suatu praktik perawatan yang diperlukan sehingga memberikan perlindungan yang baik untuk pasien dengan kondisi termal dan mememberikan kenyamanan tersendiri oleh keluarga pasien, tindakan memberikan prakti dalam pencegahan resiko jatuh sesuai dengan hadist yang diriwayatkan oleh Jabir Radhiallahu'anhu bahwa Rasulullah shallallahu 'alaihi wa sallam bersabda "Barang siapa di antara kalian yang mampu memberi kemanfaatan bagi saudaranya maka hendaknya dia lakukan" hadist ini menunjukan bahwa seseorang yang mampu memberikan manfaat yang berguna kepada orang lain maka hendaknya dilakukan Allah akan memberikan ridho tersendiri untuk orang - orang yang mau memberikan manfaat kepada orang lain yang membutuhkan, peran perawat dalam menjaga kesehatan dan memberikan kesembuhan bagi pasien sangatlah terhormat dan berfaidah dalam menjalani suatu kehidupannya seperti menjaga pasien jatuh dan mengalami kecelakaan kesehatan yang dirinya tidak bisa melakukan pencegahan.

Begitu pula pendapat Stanley (2009) mengatakan Jatuh dapat mengakibatkan berbagai jenis cedera, kerusakan fisik dan psikologis. Kerusakan fisik yang paling ditakuti dari kejadian jatuh adalah patah tulang panggul. Jenis fraktur lain yang sering terjadi akibat jatuh adalah fraktur pergelangan tangan, lengan atas dan pelvis serta kerusakan jaringan lunak. Dampak psiko logis adalah walaupun cedera fisik tidak terjadi, syok setelah jatuh dan rasa takut akan jatuh lagi dapat memiliki banyak konsekuensi termasuk ansietas, hilangnya rasa percaya diri, penbatasan dalam aktivitas seharihari, falafobia atau fobia jatuh sehingga diperlukan pencegahan yang segera supaya pasien terhindar dari resiko jatuh dan cidera yang mengakibatkan pasien menjadi cidera dan sakit berkepanjangan.

\section{KESIMPULAN}

Motivasi dalam pencegahan resiko jatuh pada anak yang memiliki kategori baik sebanyak 69 orang $(63,9 \%)$ sedangkan yang memiliki kategori cukup yaitu sebanyak 39 orang $(36,3 \%)$.Praktik perawat dalam pencegahan resiko jatuh pada anak yang memiliki kategori baik sebanyak 54 orang $(50 \%)$ sedangkan yang memilikikategori cukup sebanyak 54 orang $(50 \%)$.

Terdapat hubungan yang signifikan antara motivasi dengan Praktik perawat dalam pencegahan resiko jatuh pada anak di ruang anak Rumah Sakit Kabupaten Kendal yang ditunjukkan dengan nilai $\mathrm{p}$ value sebesar 0,012<0,05.

Saran :Dapat meningkatkan pelayanan terutama berkaitan dengan keselamatan 
pasien pada pasien yang dirawat di rumah sakit dengan resiko jatuh pada anak

\section{UCAPAN TERIMAKASIH}

Ucapan terimakasih kami haturkan kepada RSUD Kabupaten Kendal dan STIKES Muhammadiyah Kendal serta orang-orang yang terlibat dan memberikan kontribusi dalam penelitian ini.

\section{DAFTAR PUSTAKA}

Azwar, Saifuddin. (2019). Penyusunan Skala Psikologi (Edisi II). Yogyakarta: Pustaka Pelajar.

Brooks, G.F., Carroll, K.C., Butel, J.S., dan Morse, S.A. (2018). Jawetz, Melnick, \& Adelberg's Medical Microbiology. 24th ed. United States of America: The McGraw-Hill Companies, Inc.

Budiman, dan Riyanto Agus. (2013). Pengetahuan dan Sikap Dalam Penelitian Kesehatan. Jakarta: Salemba Medika.

Cintya, Bawelle Selleya. (2013). Hubungan Pengetahuan dan Sikap Perawat dengan Pelaksanaaan Keselamatan Pasien (Patient Safety) Di Ruang Rawat Inap RSUD Liun Kendage.ejournal Keperawatan (e-Kp). 1.

Damayanti, Ika Putri, dkk.(2018). Buku Ajar Asuhan Kebidanan Komprehensip pada Ibu Bersalin dan Bayi baru Lahir. Yogyakarta: deepublish.
Departemen Kesehatan Republik Indonesia. (2016). Panduan Nasional Keselamatan Pasien Rumah Sakit (Patient Safety). Jakarta: Departemen Kesehatan Republik Indonesia.

Diadjeng,S.W. (2019). Kepatuhan Bidan

Praktek Swasta dalam Pelaporan Pencatatan Pelayanan KIA di

Kabupaten Blitar Propinsi Jawa Timur. Jurnal Kesehatan Masyarakat. Volume 23, Nomor 4

Krisnawati, Wijaya \& Suarjana. (2016). Hubungan Motivasi dan Komitmen Kerja Perawat dengan Penerapan Keselamatan pasien di Ruang Intensif RSUP Sanglah Denpasar Journal COPING (Community of Publishing in Nursing). Vol.4 No. 3 Dari :https://ojs.unud.ac.id/index. php/coping/article/view/32451.

Makta. (2013). Pengaruh Motivasi Kerja dengan Kinerja Perawat Pelaksana di Unit RawatInap RS Stella Maris Makassar. Universitas Hasanuddin. Dari

https://core.ac.uk/download/pdf/25491 276.pdf

Nanang Yulianto Prabowo. (2014). Hubungan Tingkat Pengetahuan Perawat Terhadap Pelaksanaan Pengkajian Resikojatuh Skala Morse Di Rs Pku Muhammadiyah Yogyakarta Unit 2. Yogyakarta ; Dari

http://thesis.umy.ac.id/datapublik/t342 58.pdf 
Notoatmodjo, S. (2012). Metodologi Penelitian Kesehatan. Jakarta : Rineka Cipta.

Oktaviani, Hesti. (2015). Hubungan Pengetahuan Dengan Kepatuhan Perawat Dalam Pelaksanaan Standar Prosedur Oprasional Pencegahan Resiko Jatuh Pasien Di Rumah Sakit Panti Waluyo Surakarta. Dari : https://adoc.tips/hesti-oktaviani-1-sdwi-sulisetyawati-2-rufaida-nurfitriana.html

Sadili. (2010). Mengajarkan Emotional Intelligence pada Anak. Jakarta: Gramedia

Setiadi. (2017). Konsep dan Penulisan Riset Keperawatan. Yogyakarta : Graha Ilmu.

Soekidjo, (2012) Konsep dan Penerapan Metodologi Penelitan Ilmu Keperawatan. Jakarta: Selemba Medika.

Stanley. (2009). Pola Komunikasi Orangtua dan Anak dalam Keluarga. Jakarta : PT. RenekaCipta

Sugeng Budiono, Arief Alamsyah, Tri Wahyu S. (2014). Pelaksanaan Program Manajemen Pasien dengan Risiko Jatuh di Rumah Sakit Semarang : Badan Penerbit UNDIP.

Wasis. (2018). Pedoman Riset Praktis Untuk Profesi Perawat. Jakarta: EGC

WHO. (2019). Fall Rísk. Dari www. WHO. Int. .
Wibowo. (2014). Manajemen Kinerja, Edisi keempat. Jakarta : Rajawali Pers,

Wong, Donna 1,dkk ( 2009 ). Buku Ajar Keperawatan Pediatrik, Volume 2, Jakarta : EGC.

World Health Organization. (2019). Physical Activity and Older Adults. Dari : http://www.who.int/ dietphysicalactivity/factsheet_olderad ults/en/. 